\title{
Urgences
}

\section{Octobre au jardin pétrifié}

\section{Denise Houle}

Numéro 16, mars 1987

D.G. Jones : d'un texte, d'autres

URI : https://id.erudit.org/iderudit/025393ar

DOI : https://doi.org/10.7202/025393ar

Aller au sommaire du numéro

Éditeur(s)

Urgences

ISSN

0226-9554 (imprimé)

1927-3924 (numérique)

Découvrir la revue

Citer ce document

Houle, D. (1987). Octobre au jardin pétrifié. Urgences, (16), 60-61. https://doi.org/10.7202/025393ar d'utilisation que vous pouvez consulter en ligne.

https://apropos.erudit.org/fr/usagers/politique-dutilisation/ 


\section{Denise Houle OCTOBRE AU JARDIN PÉTRIFIÉ}

Sous la pluie, chavirent

les ombres, se noient

les fleurs

Les feuilles à la dérive emmêlent leurs couleurs.

Alors

c'est une floraison de pierres

rangées comme de grands livres

où la voix des Anciens

nous parle toujours.

Encore et encore des cailloux

comblent ma bouche

et les os de mes congénères

ressemblent à des fleurs.

Est-ce le chaos, le paradis, le temple d'Angkor Vat

ou la grande ville, la nuit? Il n'y a rien

de vivant, de mort ou d'humain.

Là où je passe, à la brunante, sous la pluie. Le mystère s'étend... à l'infini. 


\section{DIFFICULTÉS}

D'abord, comment rendre ce roulement produit par la répétition de la consonne "r» (rain-ruin-flowers) dans la première strophe? J'ai choisi pour rendre l'idée de ruine: chavirent les ombres. Et le tombeau des fleurs? Ne se noient-elles pas sous la pluie trop abondante? D'autant qu'il y avait le son "n» comme dans ruin-rain.

Que les feuilles aillent à la dérive, quand les fleurs se noient, cela allait de soi.

Le plus difficile fut de traduire le mot tomes. En français, cela n'allait pas. J'ai opté pour grands livres... Je ne sais pas encore si j'ai bien fait. Quant à ceux qui sont partis? J'ai préféré: les Anciens. Ne nous parlent-ils pas encore?

Peu de difficultés pour rendre "More and more my mouth..." Encore et encore? Pas si mal. Des cailloux comblent ma bouche? Plus loin, ily aura ressemblent. J'aurais pu choisir semblables à la place de congénères mais c'était un peu trop d'assonances et puis, à la fin, j'allais avoir le mot mystère.

Le reste, sauf la dernière phrase, a été assez facile. J'ai longtemps cherché ce qu'avait voulu dire l'auteur par «runes». J'ai décidé de deviner... Et j'ai tenté: Le mystère s'étend... Quant à «growth», pourquoi pas: à l'infini? 